\title{
DAMPAK MENONTON SERIAL ANIMASI DORA THE EXPLORER TERHADAP TINGKAT KONSENTRASI SISWA SEKOLAH DASAR
}

\author{
Husni Wakhyudin, dan Dian Novita Ningrum
}

Universitas PGRI Semarang

Email: husni.wakhyu@yahoo.co.id

\section{Info Artikel}

Sejarah Artikel:

Diterima 17 September 2018

Direvisi 29 Oktober 2018

Disetujui 30 November 2018

\section{Keywords:}

Contextual; Integrated Science.

\begin{abstract}
The purpose of this research is to know the impact of watching animated series Dora The Explorer to the level of student concentration in SD Negeri Tinjomoyo 01 Semarang. The approach used in this research is qualitative descriptive research approach that is research that describes events or phenomena with data in the form of information or words. Qualitative approach is expected to produce a deep description of the words, writings and behavior observed from an individual, groups, communities and organizations in a given contextual situation studied in a comprehensive, holistic and holistic perspective. This approach is used to describe and describe the focus of research, namely the analysis of the impact of watching the animated series Dora The Explorer to the level of student concentration. The emergence of student learning behavior in this study researchers can describe as follows: the emergence of student cognitive behavior as many as 30 students, as many as 30 students, the appearance of psychomotor behavior of students as much as 35 students and the appearance of language behavior as many as 29 students. So it can be said that the concentration level of students when the animated series Dora The Explorer animation is high.
\end{abstract}

\begin{abstract}
Abstrak
Tujuan penelitian ini adalah untuk mengetahui adanya dampak menonton serial animasi Dora The Explorer terhadap tingkat konsentrasi siswa di SD Negeri Tinjomoyo 01 Semarang. Pendekatan yang digunakan dalam penelitian ini adalah pendekatan penelitian deskriptif kualitatif yaitu penelitian yang menggambarkan peristiwa atau fenomena dengan data-data yang berbentuk informasi atau kata-kata. Pendekatan kualitatif diharapkan mampu menghasilkan uraian yang mendalam tentang ucapan, tulisan dan perilaku yang diamati dari suatu individu, kelompok, masyarakat dan organisasi tertentu dalam suatu keadaan konteks tertentu yang dikaji dalam sudut pandang yang utuh, komprehensif dan holistik. Pendekatan ini digunakan untuk menjabarkan dan mendeskripsikan fokus penelitian, yaitu mengenai analisis dampak menonton serial animasi Dora The Explorer terhadap tingkat konsentrasi siswa. Pemunculan perilaku belajar siswa pada penelitian ini dapat peneliti uraikan sebagai berikut: pemunculan perilaku kognitif siswa sebanyak 30 siswa, pemunculan perilaku afektif siswa sebanyak 30 siswa, pemunculan perilaku psikomotor siswa sebanyak 35 siswa dan pemunculan perilaku berbahasa sebanyak 29 siswa. Dapat dikatakan bahwa tingkat konsentrasi siswa saat penayangan serial animasi Dora The Explorer adalah tinggi.
\end{abstract}


Wakhyudin, Husni., dan Ningrum, Dian Novita.

DAMPAK MENONTON SERIAL ANIMASI DORA THE EXPLORER TERHADAP ...

REFLEKSI EDUKATIKA: Jurnal Ilmiah Kependidikan, Nomor 9, Volume 1, Desember 2018, hlm. 56-64

\section{PENDAHULUAN}

Kartun masih menjadi daya tarik tersendiri bagi anak-anak. Ada beberapa kartun yang menggambarkan sisi pembelajaran, dapat memberikan contoh yang baik, sehingga ketika ditonton oleh anak, kartun tersebut layak dikonsumsi anak-anak. Contoh dalam kartun tersebut menyuguhkan tentang budaya tolongmenolong, pentingnya sifat kejujuran, dan tema lain bersifat positif. Sejarahnya, film animasi atau yang lebih popular dengan sebutan film kartun, pada awalnya memang dibuat sebagai sarana hiburan untuk anak-anak.

Tayangan yang disajikan oleh televisi pada anak-anak saat ini masih di dominasi oleh serial animasi, salah satu animasi kartun yang sangat digemari anak-anak saat ini adalah Dora the Explorer. Dora the Explorer adalah animasi televisi anak-anak dari Amerika Serikat milik jaringan televisi kabel Nickelodeon. Episode percobaan disiarkan tahun 1999 dan menjadi serial regular mulai tahun 2000 serial ini dibuat oleh Chris Gifford, Valerie Walsh, dan Erick Weinner (Subandy 2007).

Tokoh utama serial ini adalah seorang gadis kecil yang baik hati dan senang berpetualang menjelajahi hutan. Dora selalu di temani oleh Boots, seekor monyet. Mereka berdua menjelajah untuk membantu seorang teman atau mencari sesuatu yang mereka butuhkan. Sepanjang perjalanan mereka dibantu oleh beberapa teman, seperti keluarga dan saudara Dora, juga binatang-binatang, tumbuhan, atau benda yang bisa berbicara lainnya. Meski begitu Dora tetap mandiri. Ketika menjelajahi hutan mereka menemukan petualanganpetualangan menarik yang dipecahkan secara logis.

Cerita Dora the Explorer dikemas dalam tayangan yang aman dikonsumsi oleh anak-anak, bahkan oleh balita. Tidak ada kekerasan dalam serial animasi ini. Tayangan ini menyajikan nyanyian-nyanyian oleh Dora dan kawankawannya ketika berpetualang. Pada tayangan serial ini juga diajarkan tentang bagaimana berlaku baik terhadap sesama, saling tolongmenolong, tidak mudah menyerah, dan selalu belajar dan terus belajar. Selain itu, serial animasi Dora the Explorer juga mempunyai fungsi untuk mengajak anak-anak mengembangkan keterampilan, salah satunya adalah berfikir dan berkonsentrasi memecahkan masalah konsentrasi sangat penting dalam kehidupan manusia.
Hal ini berkaitan dengan usaha manusia memfokuskan perhatian pada suatu objek sehingga dapat memahami dan mengerti objek yang diperlihatkan. Jika manusia tidak dapat berkonsentrasi perhatiannya mudah beralih dari satu objek ke objek lain dengan demikian kurang mampu memahami suatu objek secara utuh. Anak yang terganggu konsentrasinya mengalami kesulitan untuk memfokuskan konsentrasi, dan perhatiannya. Mereka sering lupa intruksiintruksi yang diberikan. Proses pembelajaran membutuhkan konsentrasi, oleh karena itu setiap anak dalam mengikuti proses pembelajaran di sekolah diharapkan dapat berkonsentrasi dengan baik, sehingga anak mampu menangkap setiap materi atau pelajaran yang diberikan oleh guru di sekolah. Konteks serial animasi ini disandarkan pada filsafat pembelajaran yang ingin disampaikan oleh para kreator melalui berbagai episode yang ditayangkan.

Cerita Dora the Explorer ini terlihat sederhana, lucu, dan menarik. Dalam kaitan ini dapat diketahui bahwa tayangan serial animasi Dora the Explorer berpengaruh terhadap tingkat konsentrasi dan daya ingat anak. Karena serial animasi tersebut memberikan instruksi-instruksi, sehingga anak-anak terlibat dalam aktifitas yang dilakukan Dora dan Boots. Hal ini menjadi daya tarik penulis untuk melakukan penelitian sehubungan analisis dampak menonton serial animasi Dora the Explorer terhadap tingkat konsentrasi siswa di SD N Tinjomoyo 01 Semarang.

Penelitian ini memiliki tujuan yang hendak dicapai yakni untuk mengetahui adanya dampak menonton serial animasi Dora the Explorer terhadap tingkat konsentrasi siswa di SD N Tinjomoyo 01 Semarang.

\section{METODE PENELITIAN}

Jenis penelitian yang digunakan dalam penelitian ini adalah penelitian kualitatif. Penelitian ini dilakukan di SDN Tinjomoyo 01 Semarang pada tanggal 15-18 November 2017. Teknik pengumpulan data yang digunakan dalam penelitian ini adalah: Observasi langsung, wawancara, dan dokumentasi.

Observasi langsung adalah pengamatan langsung kepada obyek penelitian, sedangkan yang menjadi obyek observasi adalah siswa. Alat yang digunakan berupa angket pengamatan observasi, serial animasi Dora the expolorer dan LCD. Fokus observasi akan berkembang selama kegiatan observasi berlangsung. 
Wakhyudin, Husni., dan Ningrum, Dian Novita.

DAMPAK MENONTON SERIAL ANIMASI DORA THE EXPLORER TERHADAP ...

REFLEKSI EDUKATIKA: Jurnal Ilmiah Kependidikan, Nomor 9, Volume 1, Desember 2018, hlm. 56-64

Wawancara yang dipergunakan oleh peneliti dalam penelitian ini adalah wawancara terstruktur. Yakni wawancara yang pewawancaranya menetapkan sendiri masalah dari pertanyaan-pertanyaan yang akan diajukan (Sugiyono 2015: 319). Pada saat melakukan wawancara, peneliti telah menyiapkan pedoman wawancara yang berupa pertanyaan-pertanyaan tertulis untuk mengetahui fakta, data pengetahuan, konsep, pendapat, atau persepsi responden mengenai nilai moral yang berkembang dimasyarakat. Wawancara penelitian ini ditujukan pada guru dan orang tua siswa sebagai responden.

Teknik dokumentasi digunakan peneliti untuk memperoleh bukti data nyata penelitian. Bukti tambahan lainnya diperoleh dari foto, baik itu foto tentang informan, kegiatan pembelajaran, keadaan sumber data dan lokasi penelitian. Dengan foto ini diharapkan kredibilitas penelitian ini dapat dipertanggung jawabkan karena dapat menggambarkan sifat-sifat khas dari kasus yang diteliti.

Cara pengujian kreadibilitas data hasil kualitatif antara lain: dilakukan dengan perpanjangan pengamatan, peningkatan ketekunan dalam penelitian, triangulasi, diskusi dengan teman sejawat, analisis, kasus negatif dan member check. Dalam penelitian ini uji keabsahan data yang digunakan yaitu perpanjangan pengamatan, meningkatkan ketekunan peneliti, triangulansi sumber, dan member check. Perpanjangan pengamatan yang dilakukan peneliti dengan cara memperpanjang waktu menyimak, memahami dan mengkaji tingkat konsentrasi yang terdapat dalam serial animasi Dora the Explorer.

Meningkatkan ketekunan diharapkan dapat memberikan deskripsi data yang akurat dan sistematis. Peneliti melakukan peningkatan ketekunan dengan cara menyimak dan memahami serial animasi Dora the Explorer dengan teliti dan jeli supaya pada akhir penelitian tidak terjadi kesalahan saat mengkaji tingkat konsentrasi pada serial animasi Dora the Explorer.

Triangulasi dalam pengujian kredibilitas ini dapat diartikan sebagai pengecekan data dari berbagai sumber dengan berbagai cara, dan berbagai waktu. Apabila data yang ditemukan peneliti disepakati oleh pemberi data, maka data tersebut valid.

Metode penelitian menjelaskan rancangan kegiatan, ruang lingkup atau objek, bahan dan alat utama, tempat, teknik pengumpulan data, definisi operasional variabel penelitian, dan teknik analisis. Mengenai uraian metode penelitian yang digunakan secara ringkas. Apabila terdapat metode yang tidak umum digunakan, maka harus diuraikan secara rinci. Adapun prosedur yang digunakan dalam penelitian dapat digambarkan dalam bentuk diagram alir, gambar atau diagram lain yang menunjang.

Penelitian ini menggunakan teknik analisis yang terdiri dari tahap reduksidata, penyajian data, verifikasi/ penarikan kesimpulan. Mereduksi data berarti merangkum, memilih halhal yang pokok, memfokuskan pada hal-hal yang penting, dicari tema dan polanya dan membuang yang tidak perlu (Sugiyono 2014: 338). Data yang diperoleh peneliti dari lapangan merupakan data yang masih komplek, sehingga peneliti perlu mereduksi data tersebut dengan cara merangkum, memilih hal-hal yang pokok, dan memfokuskan pada hal yang lebih jelas agar mempermudah peneliti.

Data direduksi, maka langkah selanjutnya dalah mendisplay data. Dalam penelitian kualitatif, penyajian data dilakukan dalam bentuk uraian singkat, bagan, hubungan antar kategori, flowchart, dan sejenisnya (Sugiyono 2014: 341). Penelitian ini menyajikan data dalam bentuk teks yang bersifat naratif, bagan untuk memudahkan peneliti memahami peristiwa yang terjadi. Sugiyono (2013: 341) mengemukakan bahwa setelah data direduksi, maka langkah selanjutnya adalah mendisplaykan data.

Wawancara dilakukan pada guru, siswa dan orang tua siswa yang akan diobservasi hasil berupa deskripsi tentang hasil wawancara yang telah dilakukan selama penelitian. Peneliti menggunakan tabel untuk menyajikan data yang telah dianalisis dengan memasukkan tokohtokoh, tingkat konsentrasi dan kalimat.

Prosedur yang terakhir, peneliti akan menarik kesimpulan dari penyajian data yang telah dilakukan. Simpulan dalam penelitian kualitatif yang diharapkan adalah merupakan temuan baru yang sebelumnya belum pernah ada. Temuan dapat berupa deskripsi atau gambaran suatu objek yang sebelumnya masih remangremang atau gelap sehingga setelah diteliti menjadi jelas, dapat berupa hubungan kausal atau interaktif, hipotesis, atau teori (Sugiyono 2014: 345).

Metode analisis data adalah cara yang digunakan untuk menganalisis data yang diperoleh dengan tujuan penelitian. Dalam menganalisis data ini dilakukan tahap-tahap 
Wakhyudin, Husni., dan Ningrum, Dian Novita.

DAMPAK MENONTON SERIAL ANIMASI DORA THE EXPLORER TERHADAP ...

REFLEKSI EDUKATIKA: Jurnal Ilmiah Kependidikan, Nomor 9, Volume 1, Desember 2018, hlm. 56-64

sebagai berikut: (1) menonton serial animasi Dora the Explorer, (2) menganalisis tingkat konsentrasi pada serial animasi Dora the Explorer, dan (3) menyimpulkan hasil analisis tingkat konsentrasi pada serial animasi Dora the Explorer.

Langkah-langkah analisis data dalam penelitian ini yang pertama adalah reduksi data (data reduction). Mereduksi data berarti merangkum, memilih hal-hal yang pokok, memfokuskan pada hal-hal yang penting, dicari tema dan polanya dan membuang yang tidak perlu (Sugiyono, 2014: 338). Data yang diperoleh peneliti dari lapangan merupakan data yang masih komplek, sehingga peneliti perlu mereduksi data tersebut dengan cara merangkum, memilih hal-hal yang pokok, dan memfokuskan pada hal yang lebih jelas agar mempermudah peneliti.

Data direduksi, maka langkah selanjutnya dalah mendisplay data. Dalam penelitian kualitatif, penyajian data dilakukan dalam bentuk uraian singkat, bagan, hubungan antar kategori, flowchart, dan sejenisnya (Sugiyono 2014: 341). Penelitian ini peneliti menyajikan data dalam bentuk teks yang bersifat naratif, bagan untuk memudahkan peneliti memahami peristiwa yang terjadi. Sugiyono (2013: 341) mengemukakan bahwa setelah data direduksi, maka langkah selanjutnya adalah mendisplaykan data.

Wawancara dilakukan pada guru, siswa dan orang tua siswa yang akan diobservasi hasil berupa deskripsi tentang hasil wawancara yang telah dilakukan selama penelitian. Peneliti menggunakan tabel untuk menyajikan data yang telah dianalisis dengan memasukkan tokohtokoh, tingkat konsentrasi dan kalimat.

Prosedur yang terakhir, peneliti akan menarik kesimpulan dari penyajian data yang telah dilakukan. Simpulan dalam penelitian kualitatif yang diharapkan adalah merupakan temuan baru yang sebelumnya belum pernah ada. Sugiyono (2014: 345) mengemukakan temuan dapat berupa deskripsi atau gambaran suatu objek yang sebelumnya masih remang-remang atau gelap setelah diteliti menjadi jelas, dapat berupa hubungan kausal atau interaktif, hipotesis, atau teori.

Tahapan penelitian dimulai dari menyusun rencana penelitian. Menyusun rencana penelitian sesuai dengan apa yang telah dilaksanakan dalam penelitian tersebut yaitu mengumpulkan informasi dari berbagai teknik pengumpulan data seerti wawancara, dokumentasi, dan pengamatan. Kedua memilih lapangan penelitian. Sesuai dengan permasalahan yang diangkat dalam penelitian ini, maka penulis memilih lokasi penelitian yang digunakan sebagai sumber data. Lokasi penelitian yang peneliti lakukan berada di SD Negeri Tinjomoyo 01 Semarang, ruang guru SD Negeri Tinjomoyo 01 Semarang dan rumah siswa.

Penelitian kualitatif dalam setting penelitiannya sebenarnya tidak terikat oleh waktu dan tempat, namun dalam penelitian ini tetap menentukan lokasi penelitian untuk melakukan wawancara dengan responden. Waktu dalam penelitian ini tidak ditentukan seberapa cepat atau lama, namun disesuaikan dengan kondisi si peneliti dan responden. Khusus untuk penlitian analisis serial animasi anak, penliti tidak menjadwal secara terprogram. Peneliti melakukan analisis di meja peneliti tanpa ada keterikatan.

Ketiga adalah mengurus Perizinan. Berdasarkan rancangan rumusan masalah, sumber data, dan lokasi penelitian, peneliti mengurus berbagai hal yang diperlukan untuk kelancaran kegiatan penelitian. Peneliti sebelumnya mengajukan proposal peneletian hingga memperoleh persetujuan untuk melakukan kegiatan penelitian. Peneliti mengajukan surat izin penelitian kepada pihak kampus Universitas PGRI Semarang terkait guna kelancaran perizinan pada lokasi penelitian. Surat izin penelitian diserahkan kepada Kepala Sekolah Bapak Puji Haryanto, S.Pd., M.Si SDN Tinjomoyo 01 Semarang selanjutnya peneliti mendiskusikan dan menentukan waktu yang disesuaikan dengan kondisi sekolah agar tidak mengganggu proses belajar mengajar.

Tahapan keempat adalah menjajaki dan menilai lapangan. Peneliti melengkapi administrasi yang diperoleh sebagai bekal legalisasi kegiatan penelitian. Pada tahap menjajaki dan menilai keadaan, penelitian tidak mengalami kesulitan dalam proses penjajakan lapangan dan sosialisasi diri dengan keadaan di lapangan. Di lapangan, para responden dan pihak terkait lainnya dapat menerima penliti menjadi bagian dari Sekolah Dasar Negeri Tinjomoyo 01 Semarang, sehingga peneliti dengan mudah menggali data penelitian.

Tahapan yang kelima adalah memilih dan memanfaatkan informasi. Informan dalam penelitian ini terdiri dari: Guru SD Negeri Tinjomoyo 01 Semarang yaitu Bapak Budiyono, S.Pd (Guru kelas IV A), Guru SD Negeri Tinjomoyo 01 Semarang yaitu Ibu Sri Subekti, S.Pd (Guru kelas II A), Guru SD Negeri 
Wakhyudin, Husni., dan Ningrum, Dian Novita.

DAMPAK MENONTON SERIAL ANIMASI DORA THE EXPLORER TERHADAP ...

REFLEKSI EDUKATIKA: Jurnal Ilmiah Kependidikan, Nomor 9, Volume 1, Desember 2018, hlm. 56-64

Tinjomoyo 01 Semarang yaitu Melisa Indriyanti, S.Pd (Guru kelas II B), Guru SD Negeri Tinjomoyo 01 Semarang yaitu Ibu Rusmiyati, S.Pd (Guru kelas I A), Guru SD Negeri Tinjomoyo 01 Semarang yaitu Ibu Elisa Rahmawati, S.Pd (Guru kelas II B), orang tua siswa sebanyak 7 orang dan siswa kelas II B sebanyak 38 orang.

Tahapan penelitian yang keenam adalah menyiapkan perlengkapan penelitian. Peneliti menyiapkan perlengkapan penelitian baik berupa fisik maupun non fisik yang digunakan untuk bahan penelitian. Peneliti juga harus menyiapkan mental karena dalam melaksanakan penelitian dibutuhkan tata cara peneliti dengan sikap yang sopan, tidak menganggu kegiatan guru, dan siswa, dan proses pembelajaran yang berlangsung, serta mendapatkan informasi sejelas-jelasnya tanpa adanya rekayasa keadaan di lapangan. Peneliti juga harus membuat seperangkat teknik dalam mengumpulkan data seperti pedoman wawancara, angket dan pedoman observasi.

Tahapan yang terakhir adalah persoalan etika penelitian. Peneliti harus bisa mempersiapkan sikap dan mental dalam melaksanakan kegiaan penelitian agar bisa muncul rasa saling menghormati satu sama lain antar peneliti dengan guru, yang sedang diobservasi. Sebelum melaksanakan penelitian harus izin terlebih dahulu dan setelah selesai melaksanakan penelitian harus meminta izin dengan baik dan sopan sambil mengucapkan terima kasih, kegiatan observasi jangan sampai mengganggu proses pembelajaran, dan kegiatan orang tua siswa atau menyinggung perasaan yang diobservasi.

\section{HASIL DAN PEMBAHASAN}

Peneliti melakukan penelitian terhitung sejak tanggal 15-18 November 2017. Setiap tahapan yang terjadi tidak berjalan secara mutlak, namun bisa diselingi dengan tahap selanjutnya demi efektifitas waktu tanpa mengurangi esensi dari penelitian itu sendiri. Penelitian dilakukan dengan mengobservasi siswa dan dibantu angket serta wawancara

Observasi pada penelitian ini ditujukan kepada siswa. Siswa yang diobservasi sebanyak 38 orang. Observasi dilakukan pada tanggal 16 November 2017. Hasil observasi menunjukkan bahwa anak sekolah dasar lebih tertarik belajar menggunakan sesuatu yang membuatnya senang. Anak-anak cenderung lebih aktif untuk menunjukkan kreatifitas dan kecerdasannya. Hal itu membuat anak terfokus pada satu objek saja. Siswa sangat antusias ketika mengetahui akan ditayangkan serial animasi Dora the Explorer. Siswa langsung berbaris dan masuk kedalam kelas dengan tertib. Kemudian anak duduk dibangkunya masing-masing, tidak ada siswa yang mengobrol dengan teman sebangkunya. Saat penayangan serial animasi Dora the Explorer ditayangkan siswa memperhatikan dengan seksama. Siswa menyimak setiap adegan yang ada dalam serial animasi Dora the Explorer dengan keadaan yang rileks dan suasana yang menyenangankan. Suasana menyenangkan dalam hal ini berarti anak berada dalam keadaan yang sangat rileks, tidak berada dalam keadaan yang mengancam dirinya baik fisik maupun non fisik (Prihastuti 2009).

Dalam observasi ini terlihat juga, bahwa siswa menunjukkan perilaku kognitif, perilaku afektif, perilaku psikomotor dan perilaku berbahasa yang berbeda-beda sesuai dengan yang dijelaskan Engkoswara dalam Tabrani (1989: 10). Perilaku kognitif yang terlihat adalah anak mampu mengaplikasikan pengetahuan yang diperoleh dan mampu mengadakan analisis dan sintesis pengetahuan yang diperoleh. Hal ini di tunjukkan dengan adanya usaha siswa untuk berkonsentrasi dan terfokus pada tayangan serial animasi Dora the Explorer. Siswa berusaha berkonsentrasi pada setiap instruksi yang ada didalam serial animasi Dora the Explorer.

Perilaku afektif juga terlihat saat penayangan serial animasi Dora the Explorer. Perilaku afektif ditunjukkan dengan adanya tingkat perhatian tertentu kemudian merespon atau keinginan untuk mereaksi bahan yang diajarkan. Konsentrasi siswa tidak terbagi-bagi saat penayangan serial animasi Dora the Explorer seperti mencari kesibukan lain, berbicara dengan teman dan ramai, kemudian siswa membuktikannya dengan menjawab atau merespon setiap instruksi yang ada didalam serial animasi Dora the Explorer. Bahkan siswa masih mengingat lagu dan instruksi yang ada dalam serial animasi Dora the Explorer setelah film tersebut berakhir.

Siswa tidak hanya diam ditempat duduk, namun juga melakukan gerakan sesuai dengan instruski yang ada dalam serial animasi Dora the Explorer. Siswa menirukan apa yang dilakukan Dora seperti mendorong, menarik, menghentikan Swipper, menyanyi, melompat dan lain-lain. Pernyataan tersebut sesuai dengan perilaku 
Wakhyudin, Husni., dan Ningrum, Dian Novita.

DAMPAK MENONTON SERIAL ANIMASI DORA THE EXPLORER TERHADAP ...

REFLEKSI EDUKATIKA: Jurnal Ilmiah Kependidikan, Nomor 9, Volume 1, Desember 2018, hlm. 56-64

psikomotor yaitu adanya gerakan anggota badan yang tepat atau sesuai dengan petunjuk guru dan komunikasi non verbal seperti ekspresi muka dan gerakan-gerakan yang penuh arti.

Perilaku selanjutnya yang terlihat saat penayangan serial animasi Dora the Explorer adalah perilaku berbahasa. Sesuai yang telah dijelaskan pada Bab II, perilaku berbahasa ditengarai dengan adanya aktivitas berbahasa yang baik (Engkoswara dalam Tabrani, 1989: 10). Komitmen siswa akan antusiasme penayangan serial animasi Dora the Explorer sejak awal dipertahankan hingga akhir tayangan. Komitmen anak ditunjukkan dengan kondisi fisik, emosional dan psikologi anak yang baik. Anak merasa senang dan tidak berbebani.

Berdasarkan dari deskripsi observasi diatas dapat dilihat sebagian besar siswa memperhatikan atau berkonsentrasi saat ditayangkan serial animasi Dora the Explorer. Siswa lebih aktif saat merespon instruksiinstruksi yang ada didalam serial animasi Dora the Explorer. Bahkan ketika tayangan serial animasi Dora the Explorer siswa masih mampu mengingat semua instruksi yang ada didalam serial animasi Dora the Explorer, memicu keterampilan psikomotoriknya. Rekapitulasi hasil observasi dapat dilihat pada tabel di bawah ini.

Tabel 1. Rekapitulasi Hasil Observasi Siswa

\begin{tabular}{|c|c|c|c|c|}
\hline No & Aspek yang diamati & \multicolumn{2}{|c|}{ Pemunculan Hasil Pengamatan } & Kategori \\
\hline 1 & Perilaku Kognitif & 30 siswa (aktif) & 8 siswa (pasif) & Tinggi \\
\hline 2 & Perilaku Afektif & 30 siswa (aktif) & 8 siswa (pasif) & \\
\hline 3 & Perilaku Psikomotor & 35 siswa (aktif) & 3 siswa (pasif) & Sedang \\
\hline 4 & Perilaku Berbahasa & 29 siswa (aktif) & 9 siswa (pasif) & Rendah \\
\hline & Total & 124 & 28 & \\
\hline
\end{tabular}

Berdasarkan rekapitulasi observasi siswa, terlihat bahwa dari 38 siswa yang ada di kelas II B, sebanyak 30 siswa mampu mampu memunculkan perilaku kognitif, 30 siswa mampu memunculkan perilaku afektif, 35 siswa mampu memunculkan perilaku psikomotor dan 29 siswa mampu memunculkan perilaku berbahasa. Ratarata siswa yang mampu memunculkan perilaku belajar secara bersamaan adalah 31 anak. Sisanya adalah siswa yang pasif dan hanya mampu memunculkan perilaku belajar secara terpisah-pisah.

Angket pada pada penelitian ini ditujukan kepada 3 subjek yaitu guru, orang tua siswa dan siswa. Angket untuk guru diberikan langsung kepada guru yang ada di SD Negeri Tinjomoyo 01 Semarang, angket untuk orang tua siswa diberikan kepada siswa untuk dibawa pulang kemudian diisi dirumah sementara untuk siswa, angket diberikan setelah siswa selesai menonton dalam serial animasi Dora the Explorer.

Berdasarkan hasil dari angket guru dan orang tua siswa, diperoleh pernyataan bahwa penyajian tayangan televisi di Indonesia beroperasi selama 24 jam. Hal ini tentu tidak akan membuat orang tertinggal informasi setiap harinya. Jam tayang pada setiap programnya belum sesuai dengan kebutuhan penonton. Sedangkan untuk perkembangan serial animasi (kartun) di Indonesia sendiri mendapatkan hasil yang kurang memuaskan. Guru dan orang tua menyatakan bahwa kartun di Indonesia masih sedikit.

Serial animasi (kartun) yang dianggap memiliki nilai edukasi atau pendidikan adalah Dora the Explorer. Format penyajian serial animasi Dora the Explorer sangat bagus. Guru dan orang tua setuju dengan format yang ditayangkan karena format penyajian serial animasi Dora the Explorer tidak hanya sekedar menghibur anak saja namun juga memberikan life skills dan melatih tingkat konsentrasi anak, sehingga anak dapat bermain sekaligus belajar tanpa adanya beban.

Pada konteks sosial yang ada dalam serial animasi Dora the Explorer berdasarkan angket menunjukkan hasil yang bagus. Karena dalam serial animasi Dora the Explorer tokoh Dora tidak digambarkan sebagai pahlawan walaupun Dora senang membantu dan menolong jika ada teman atau saudaranya membutuhkan bantuan. Dora juga selalu berterima kasih jika sudah dibantu oleh orang lain, memaafkan dan memberikan maaf.

Kecenderungan pembelajaran dalam serial animasi Dora the Explorer juga mendapatkan hasil yang baik. Tokoh utama serial animasi Dora the Explorer adalah Dora. Dora selalu 
Wakhyudin, Husni., dan Ningrum, Dian Novita.

DAMPAK MENONTON SERIAL ANIMASI DORA THE EXPLORER TERHADAP ...

REFLEKSI EDUKATIKA: Jurnal Ilmiah Kependidikan, Nomor 9, Volume 1, Desember 2018, hlm. 56-64

mengajukan pertanyaan untuk mencari jalan keluar dari setiap rintangan yang dialami dalam pertualangannya, menjawab teka-teki, mencari benda, mengahafal warna, menghitung dan mengingat jumlah benda, serta mencari jalan yang benar. Sesuai dengan pernyataan tersebut, serial animasi Dora the Explorer ini menuntut anak untuk berpikir dan berkonsentrasi namun dengan penyajian yang menyenangkan.

Analisis angket guru dan orang tua siswa diatas dapat diketahui bahwa serial animasi Dora the Explorer baik untuk dikonsumsi anak karena mengandung pembelajaran atau edukasi. Tayangan serial animasi Dora the Explorer menyajikan pembelajaran yang menarik, sehingga anak akan merasa senang ketika menonton. Anak dapat bermain sambil belajar saat menonton tayangan serial animasi Dora the Explorer. Penyajian tayangan serial animasi Dora the Explorer tidak hanya menghibur namun juga memberikan life skills dan melatih konsentrasi anak misalnya mencari jalan keluar dari setiap rintangan yang dialami dalam pertualangan Dora dan Boots, menjawab tekateki yang diajukan Dora, mencari benda, bentuk benda, warna benda dan jumlah benda.

Angket siswa diberikan kepada siswa setelah siswa selesai menonton tayangan serial animasi Dora the Explorer. Berdasarkan hasil angket yang diedarkan peneliti kepada siswa hampir setiap siswa setuju dengan format penyajian yang ditayangkan oleh serial animasi Dora the Explorer. Anak lebih tertarik belajar jika gaya penyampaiannya menyenangkan. Materi yang diberikan pun tidak menjadi beban bagi anak.

Pada konteks sosial serial animasi Dora the Explorer anak menyatakan bahwa pengaruh yang didapat saat menonton serial animasi Dora the Explorer sangat banyak. Konteks sosial tersebut adalah saling menolong, saling memaafkan, dan saling membatu. Hal tersebut merupakan sikap yang positif. Anak meniru sikap dari tokoh Dora untuk saling membantu temannya. Karena sejatinya anak akan meniru apa yang mereka lihat.

Kecenderungan pembelajaran dalam serial animasi Dora the Explorer sangat baik, sehingga anak tidak hanya sekadar menonton namun juga dapat belajar bersama dengan Dora. Materi yang disampaikan pun dikemas dalam format yang menyenangkan sehingga anak tidak akan terbebani oleh materi yang diberikan dalam serial animasi Dora the Explorer.
Berdasarkan data dari angket yang diedarkan kepada siswa terlihat bahwa anak lebih tertarik belajar jika gaya penyampaiannya menyenangkan. Konsentrasi anak tidak terbagibagi sehingga anak mampu merespon intruksi yang diberikan. Anak juga lebih mudah mengingat instruksi-instruksi yang diberikan karena format penyajiannya sangat sederhana atau tidak berbelit-belit. Anak merasa senang karena belajar menjadi menyenangkan, anak tidak merasa terbebani oleh materi yang ada di dalam serial animasi Dora the Explorer.

Dengan gaya penyampaian menyenangkan membuat anak lebih mudah mengingat instruksi dan memecahkan masalah, seperti instruksi saat menunjukkan jalan sesuai dengan peta, mengingat suara hewan, mengingat bentuk benda, mengingat jumlah benda atau hewan, menunjukkan jalan yang benar. Hal ini sesuai dengan tahap operasional konkret yang menurut Piaget anak dengan rentan usia 7-11 tahun pemikiran anak sudah mencapai logika struktur tertentu yang memungkinkan anak membentuk beberapa operasi mental namun masih terbatas pada objek-objek yang konkret.

Konteks sosial yang ada dalam serial animasi Dora the Explorer juga dapat dicontoh anak dan diaplikasikan dalam kehidupannya sehari-hari. Anak dapat mencontoh sikap Dora yang suka menolong, mandiri dalam memecahkan masalah, pandai, berkonsentrasi saat melakukan sesuatu, mengucapkan terima kasih setelah dibantu, meminta maaf jika melakukan kesalahan dan memberi maaf kepada orang lain. Berdasarkan hasil perhitungan skor angket menyatakan bahwa serial animasi Dora the Explorer adalah tayangan yang baik dan dapat melatih konsentrasi siswa.

Guru dan orang tua siswa menyatakan bahwa serial animasi Dora the Explorer tidak hanya mengihibur saja namun juga dapat melatih konsentrasi anak. Anak berlatih konsentrasi dengan cara yang menyenangkan, sehingga anak tidak merasa terbebani saat menyerap materi tersebut. Sebanyak 7 dari 12 guru menyatakan bahwa serial animasi Dora the Explorer merupakan kategori yang baik dari segi penyampaiannya hingga pembelajarannya. Sedangkan orang tua siswa sebanyak 32 dari 38 orang tua siswa juga sepakat bahwa serial animasi Dora the Explorer termasuk dalam kategori baik untuk ditonton anak.

Penyataan diatas diperkuat lagi dengan perolehan hasil angket yang diedarkan kepada siswa. Dari 38 siswa sebanyak 19 siswa 
Wakhyudin, Husni., dan Ningrum, Dian Novita.

DAMPAK MENONTON SERIAL ANIMASI DORA THE EXPLORER TERHADAP ...

REFLEKSI EDUKATIKA: Jurnal Ilmiah Kependidikan, Nomor 9, Volume 1, Desember 2018, hlm. 56-64

menyatakan tayangan serial animasi Dora the Explorer sangat baik sekali. 18 siswa menyatakan dalam kategori baik. Dapat disimpulkan bahwa serial animasi Dora the Explorer merupakan tontonan anak yang layak karena tidak hanya sekedar menghibur anak saja, namun juga menyajikan pembelajaran yang melatih konsentrasi anak.

Hasil wawancara pada penelitian ini ditujukan kepada 3 subjek yaitu guru, orang tua siswa dan siswa. Wawancara dilakukan pada tanggal 15-16 November 2017. Hasil penelitian menunjukkan bahwa anak sekolah dasar pada umumnya tidak berkonsentrasi dalam menerima materi dari guru karena adanya faktor internal dan faktor eksternal. Alasan lain anak susah untuk berkonsentrasi karena rasa bosan di dalam kelas, sehingga memicu anak untuk mencari kesibukan lain, mengobrol dengan teman, berlarian didalam kelas, makan dan minum ataupun melakukan hal-hal lain yang membuat kelas menjadi tidak terkendali.

Hasil analisis data serial animasi Dora the Explorer terlihat bahwa serial animasi Dora the Explorer menyuguhkan hal-hal yang sederhana, menanaman nilai-nilai yang jauh dari kekerasan, bahkan dapat menanamkan nilai-nilai humanistik yang bisa menjadi life skills bagi anak-anak dari sejak dini. Hal ini penting sekali bagi anak-anak karena pada usia inilah proses pengenalan dan pembelajaran yang utama dan mendasar berlangsung. Selain itu, untuk mampu survive dan berhasil dalam kehidupannya kelak, setiap anak harus diajarkan dan mengembangkan life skills, karena mereka tidak akan menjadi generasi penerus yang tangguh jika sekadar menjadi anak pintar, cerdas dan berbakat.

Dalam serial animasi Dora the Explorer yang mengandung unsur konsentrasi. Hal ini dibuktikan dengan dialog pada durasi 01:5502:08 sebagai berikut: "Dora: Ada apa bayi Bugga-Bugga?, Induk Bugga-Bugga: Aku punya sepuluh bayi tapi yang satu hilang, Dora: Apakah kalian mau membantu mencari bayi BuggaBugga? Bagaimanakah suara bayi BuggaBugga?, Bugga-Bungga: bugga bugga, bugga bugga".

Dialog diatas menunjukkan bahwa Dora menganjak audiens untuk membantu menemukan bayi Bugga-Bungga yang hilang, jumlah bayi Bugga Bugga yang hilang ada 1 . Pada adegan ini mengandung unsur tingkat konsentrasi karena Dora mengajak audien mendengarkan suara dari bayi Bugga-Bugga. Hal ini menunjukkan bahwa anak harus berkonsentrasi dan mendengarkan suara dari bayi Bugga-Bugga, anak yang berkonsentrasi akan mengingat suara dari bayi Bugga-Bugga.

Jika anak tidak berkonsentasi maka anak tidak akan menemukan bayi Bugga-Bugga yang hilang. Berdasarkan hasil penelitian yang dilakukan di SD Negeri Tinjomoyo 01 Semarang, dapat diketahui pemunculan perilaku belajar anak saat penayangan serial animasi Dora the Explorer diantarataranya perilaku Kognitif. Perilaku kognitif adalah menyangkut masalah pengetahuan, informasi dan masalah kecakapan intelektual. Pada perilaku kognitif ini, siswa yang memiliki konsentrasi belajar saat penanyangan serial animasi Dora the Explorer adalah mengaplikasikan pengetahuan yang diperoleh dan mampu mengadakan analisis dan sintesis pengetahuan. Hasil observasi dari 38 siswa, terdapat 30 siswa yang berhasil memunculkan perilaku kognitif.

Kedua adalah perilaku afektif, yaitu perilaku yang berupa sikap dan apersepsi. Pada perilaku ini siswa yang memiliki konsentrasi belajar saat penayangan serial animasi Dora the Explorer adalah adanya penerimaan dan respon. Hasil observasi dari 38 siswa, terdapat 30 siswa yang berhasil memunculkan perilaku afektif. Berikut prsentase perilaku afektif yang muncul saat penayangan serial animasi Dora the Explorer. Yang ketiga adalah perilaku psikomotor, yang dapat diartikan sebagai perilaku yang berkaitan dengan keterampilan (skill) atau kemampuan bertindak setelah seseorang menerima pengalaman belajar tertentu seperti adanya gerakan anggota badan yang tepat dan komunikasi non verbal. Dari hasil observasi dari 38 siswa, terdapat 35 siswa yang berhasil memunculkan perilaku psikomotor.

Dan yang terakhir adalah perilaku berbahasa, yakni yang menyangkut adanya aktivitas berbahasa yang terkoordinir. Pada perilaku berbahasa ini, siswa yang memiliki konsentrasi belajar saat penanyangan serial animasi Dora the Explorer bergantung pada beberapa faktor yaitu komitmen, antusiasme, keadaan fisik dan emosional siswa serta psikoligis siswa. Dari hasil observasi dari 38 siswa, terdapat 30 siswa yang berhasil memunculkan perilaku berbahasa.

Anak yang dapat dikatakan mempunyai konsentrasi tinggi adalah anak yang mampu memunculkan empat perilaku belajar sekaligus dalam waktu yang bersamaan. Peneliti memberikan kategori siswa yang mampu berkonsentrasi tinggi adalah siswa yang 
Wakhyudin, Husni., dan Ningrum, Dian Novita.

DAMPAK MENONTON SERIAL ANIMASI DORA THE EXPLORER TERHADAP ...

REFLEKSI EDUKATIKA: Jurnal Ilmiah Kependidikan, Nomor 9, Volume 1, Desember 2018, hlm. 56-64

mempunyai kriteria $66 \% \leq 100 \%$. Saat melakukan observasi didapatkan hasil bahwa kategori pemunculan perilaku belajar siswa adalah sebagai berikut: (1) perilaku kognitif memperoleh kategori baik sekali, (2) perilaku afektif memperoleh kategori baik sekali, (3) perilaku psikomotor memperoleh kategori baik sekali dan (4) perilaku berbahasa memperoleh kategori baik.

\section{SIMPULAN}

Berdasarkan hasil penelitian dapat disimpulkan bahwa di dalam serial animasi Dora the Explorer dalam setiap tayangannya mengandung pembelajaran yang melatih anak untuk berkonsentrasi dan mengembangkan keterampilan dalam (1) proses simbolik, seperti mengenal bentuk-bentuk geometris, menyesuaikan warna; (2) organisasi kognitif, seperti diskriminasi perseptual, memahami hubungan di antara objek dan peristiwa, memilih dan menyusun; (3) berpikir dan memecahkan masalah; (4) berhubungan dengan dunia fisik dan sosial.

Gaya penyampaian serial animasi Dora the Explorer menarik dan penyampaian materi yang ada didalam serial animasi Dora the Explorer lebih cenderung untuk melatih anak untuk berpikir dan berkonsentrasi yaitu pemusatan atau usaha untuk memusatkan perhatian dengan keadaan yang rileks terhdapat informasi yang dibutuhkan dengan mengabaikan informasi yang tidak diperlukan. Ciri-ciri siswa yang dapat berkonsentrasi belajar berkaitan dengan perilaku belajar yang meliputi perilaku kognitif, perilaku afektif, perilaku psikomotor dan perilaku berbahasa.

Pada penelitian ini, perilaku belajar muncul saat penayangan serial animasi Dora the Explorer. Pemunculan perilaku belajar siswa diuraikan sebagai berikut, pemunculan perilaku kognitif siswa sebanyak 30 siswa, pemunculan perilaku afektif siswa sebanyak 30 siswa, pemunculan perilaku psikomotor siswa sebanyak 35 siswa dan pemunculan perilaku berbahasa sebanyak 29 siswa.

Dapat dikatakan bahwa tingkat konsentrasi siswa saat penayangan serial animasi Dora the Explorer adalah tinggi. Karena siswa mampu memunculkan empat perilaku belajar yang menjadi ciri-cici siswa yang berkonsentrasi.

\section{DAFTAR PUSTAKA}

Aminudin. 2013. Pengantar Apresiasi Karya Sastra. Bandung: Sinar Baru Algensindo.

A'la, M. 2010. Tips Asah Ketajaman Konsentrasi Belajar Anak Setajam Silet. Yogyakarta: Flash Books.

Creswel, J. W. 2015. Penelitian Kualitatif dan Desain Riset Memilih Diantara Lima Pendekatan. Yogyakarta: Pustaka Pelajar.

Darwanto. 2011. Televisi Sebagai Media Pendidikan. Yogyakarta: Pustaka Belajar.

Dominick, J. R. 2000. The Dynamics of Mass Comumunication. New York: Random House.

Effendy, O. U. 2000. Ilmu Teori dan Filsafat Komunikasi. Bandung: PT. Citra Aditya Bakti.

Lamintang, F. T. 2012. Pengantar Ilmu Broadcasting dan Cinematografi. Jakarta: In Media.

Maarof, A. 2004. Teknologi Maklumat (Informasi Teknologi): Multimedia, Keselamatan Data dan Koridor Raya Multimedia (MSC). Kuala Lumpur: Universitas Teknologi Malaysia.

Moleong, L. J. 2014. Metodologi Penelitian Kualitatif. Bandung: PT. Remaja Rodakarya.

2016. Metodologi Penelitian Kualitatif. Bandung: PT. Remaja Rodakarya.

Morissan, M. A. 2011. Managemen Media Penyiaran Edisi Revisi. Jakarta : Kencana Prenada Media Group.

2013. Managemen Media Penyiaran: Strategi Mengelola Radio \& Televisi. Jakarta: Kencana Prenada Media Group.

Nurgiyantoro, Burhan. 2010. Sastra Anak Pengantar Pemahaman Dunia Anak. Yogyakarta: Gadjah Mada University Press. 
Wakhyudin, Husni., dan Ningrum, Dian Novita.

DAMPAK MENONTON SERIAL ANIMASI DORA THE EXPLORER TERHADAP ...

REFLEKSI EDUKATIKA: Jurnal Ilmiah Kependidikan, Nomor 9, Volume 1, Desember 2018, hlm. 56-64

Pusat Bahasa Departemen Pendidikan Nasional. 2002. Kamus Besar Bahasa Indonesia. Jakarta: Balai Pustaka.

Nuryana, Aryati. 2017. Efektivitas Brain GYM dalam Meningkatkan Konsentrasi Belajar pada Anak. Jurnal Muhammadiyah Surakarta, 8 (1).

Setyobudi, Ciptono. 2012. Teknologi Broadcasting Televisi. Yogyakarta: Graha Ilmu.

Sihabudin, dkk. 2009. Bahasa Indonesia 2. Surabaya: Anamah Pustaka.

Subandy, Dede Lilis Ch. 2017. Representasi Simbolik Film Kartun "Dora the Explorer": Ethnographick Content Analysis. Jurnal Muhamadiyah Surakarta, 8 (1).

Sugihartono, Ranang Agung, dkk. 2010. Amimasi Kartun Analog sampai Digital. Jakarta Barat: PT. Indeks.

Sugiyono. 2014. Metode Penelitian Pendidikan. Bandung: Penerbit Alfabeta.

. 2015. Metode Penelitian Pendidikan. Bandung: Penerbit Alfabeta.
Siswanto, Wahyudi. 2013. Pengantar Teori Sastra. Yogyakarta: Aditya Media Publishing.

Sujarweni, V. W. 2014. Metodologi Penelitian. Yogyakarta: Pustaka Baru Press.

Sukmadinata, N. S. 2016. Metode Penelitian Pendidikan. Bandung: PT. Remaja Rosdakarya.

Suryabrata, S. 2016. Alat Ukur Psikologis. Yogyakarta: C.V Andi.

Surya, H. 2009. Menjadi Manusia Pembelajar. Jakarta: PT. Elex Media Komputindo.

Tabrani Rusyan. 1998. Pendekatan Dalam Proses Belajar Mengajar. Bandung: CV. Remaja Karya

TIM. 2015. Pedoman Bimbingan Penulisan dan Ujian Skripsi serta Penulisan Artikel Ilmiah Mahasiswa Strata Satu Fakultas Ilmu Pendidikan. Semarang: Universitas PGRI Semarang.

Unde, A. A. 2014. Televisi dan Masyarakat Pluralistik. Jakarta: Persada Rakhmad. 